\title{
The effects of high oxygen partial pressure on vegetable Allium seeds with a short shelf-life
}

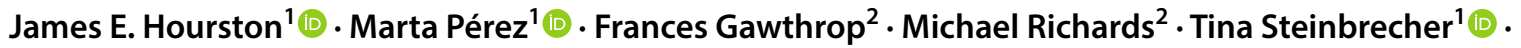 \\ Gerhard Leubner-Metzger ${ }^{1,3}$ (1)
}

Received: 10 March 2020 / Accepted: 3 May 2020 / Published online: 16 May 2020

(c) The Author(s) 2020

\begin{abstract}
Main conclusion Storage at an elevated partial pressure of oxygen and classical artificial ageing cause a rapid loss of seed viability of short-lived vegetable seeds.
\end{abstract}

\begin{abstract}
Prolonging seed longevity during storage is of major importance for gene banks and the horticultural industry. Slowing down biochemical deterioration, including oxygen-dependent deterioration caused by oxidative processes can boost longevity. This can be affected by the seed structure and the oxygen permeability of seed coat layers. Classical artificial seed ageing assays are used to estimate seed 'shelf-life' by mimicking seed ageing via incubating seeds at elevated temperature and elevated relative humidity (causing elevated equilibrium seed moisture content). In this study, we show that seed lots of vegetable Allium species are short-lived both during dry storage for several months and in seed ageing assays at elevated seed moisture levels. Micromorphological analysis of the Allium cepa $\mathrm{x}$ Allium fistulosum salad onion seed identified intact seed coat and endosperm layers. Allium seeds equilibrated at $70 \%$ relative humidity were used to investigate seed ageing at tenfold elevated partial pressure of oxygen (high $\left.\mathrm{pO}_{2}\right)$ at room temperature $\left(22^{\circ} \mathrm{C}\right)$ in comparison to classical artificial ageing at elevated temperature $\left(42^{\circ} \mathrm{C}\right)$. Our results reveal that 30 days high $\mathrm{pO}_{2}$ treatment causes a rapid loss of seed viability which quantitatively corresponded to the seed viability loss observed by $\sim 7$ days classical artificial ageing. A similar number of normal seedlings develop from the germinating (viable) proportion of seeds in the population. Many long-lived seeds first exhibit a seed vigour loss, evident from a reduced germination speed, preceding the loss in seed viability. In contrast to this, seed ageing of our short-lived Allium vegetable seems to be characterised by a rapid loss in seed viability.
\end{abstract}

Keywords Allium cepa x Allium fistulosum · Spring onion · Salad onion · Classical seed ageing · Accelerated artificial ageing $\cdot$ Controlled deterioration $\cdot$ Elevated partial pressure of oxygen (EPPO) $\cdot$ Seed longevity $\cdot$ Seed viability

Communicated by Dorothea Bartels.

Tina Steinbrecher and Gerhard Leubner-Metzger contributed equally to this work.

Gerhard Leubner-Metzger gerhard.leubner@rhul.ac.uk http://www.seedbiology.eu https://pure.royalholloway.ac.uk/portal/en/ persons/gerhard-leubner(b07cd3da-9c1d-4167-8d52-199a13 d54351).html

1 Department of Biological Sciences, Royal Holloway University of London, Egham TW20 0EX, UK

2 Tozer Seeds Ltd, Pyports, Downside Bridge Rd, Cobham KT11 3EH, UK

3 Laboratory of Growth Regulators, Palacký University and Institute of Experimental Botany, Czech Academy of Sciences, 78371 Olomouc, Czech Republic

\section{Abbreviation}

SMC Seed moisture content

\section{Introduction}

Seed longevity, the life span or 'shelf-life' of mature seeds either in the soil (wet-dry cycles), seed bank or in 'air-dry' warehouse storage, is a critical trait which varies considerably between species (Darwin 1855; Probert et al. 2009; Nagel and Börner 2010). The seed longevity trait is important for wild species as it affects the natural regeneration of plants as well as their genebank seed storage (Walters 2015; Colville and Pritchard 2019). For crop species, it is a key seed quality trait underpinning global agriculture and persistence in the soil (Walck et al. 2011; Finch-Savage and 
Bassel 2016). Considerable variation in seed longevity is evident among the desiccation-tolerant (usually 5-10\% seed moisture) species. The trait depends on genotype (cultivar), seed production environment, and seed storage conditions. The deterioration rate of seeds during storage is accelerated by elevated temperature, relative humidity $(\mathrm{RH})$, and oxygen concentration (Pritchard and Dickie 2004; Walters et al. 2005; Groot et al. 2012). Predicting seed longevity is generally achieved experimentally by classical artificial ageing assays which mimic seed deterioration in a relatively short time. These include accelerated ageing assays and controlled deterioration assays which both combine seed incubation at elevated humidity (generating an elevated equilibrium seed moisture content) and elevated temperature (Powell and Matthews 1981; Ellis et al. 1990; Pritchard and Dickie 2004; Ellis and Hong 2006). While it is clear that low ambient humidity and low temperature are hallmarks of optimal storage conditions for desiccation-tolerant seeds, it is a matter of controversial debate to what extent classical artificial ageing assays can be used to reliably predict seed longevity during storage. Further to this for quality testing in the crop seed industry, it is not known if the classical artificial ageing assays (high humidity and high temperature) can be further accelerated by high oxygen partial pressure.

Crop seed quality is compromised by ageing which initially manifests as reduced seed vigour (germination performance), then subsequently as reduced seed viability (seed death). Alongside vigour and viability loss, ageing also reduces a seed's ability to produce normal seedlings (Groot et al. 2012; Finch-Savage and Bassel 2016; Schausberger et al. 2019). Using the classical artificial ageing assays provided insight into the molecular processes underpinning the loss of seed vigour and viability. Seed ageing during storage is associated with the oxidation of macromolecules (Bailly 2004; Kranner et al. 2010; Sano et al. 2016). Progressive alterations of cell constituents (proteins, lipids, nucleic acids, sugars, etc.) occur by auto-oxidation processes such as Amadori and Maillard reactions, lipid peroxidation or protein carbonylation (e.g., Salama and Pearce 1993; Chen et al. 2013; Nagel et al. 2015; Sano et al. 2016; Schausberger et al. 2019). The ability to repair accumulated oxidative damage during seed imbibition (antioxidant systems, DNA ligases, $O$-methyltransferases), as well as the biochemical, biomechanical and micromorphological properties of the protecting seed and fruit coat layers are important in determining seed quality (Gardarin et al. 2010; Mene-Saffrane et al. 2010; Waterworth et al. 2010; Sano et al. 2016; Steinbrecher and Leubner-Metzger 2017). It is known for many crop species that mechanical damage including cracks of the seed coat through threshing or shrinkage during drying leads to a reduction in seed quality and viability (Mohamed-Yasseen et al. 1994; Pedretti et al. 2017; Salimi and Boelt 2019). The internal oxygen concentration inside a seed depends on the permeability of the seed coats for gases and on the ambient oxygen concentration (Hermann et al. 2007; Borisjuk and Rolletschek 2009; Schwember and Bradford 2011). These considerations are especially important for short-lived vegetable seeds which include onion, leek, parsnip, pepper and lettuce (Boswell et al. 1940; Justice and Bass 1978; Schwember and Bradford 2011; Roberts 2018; Selvi and Saraswathy 2018).

Ambient air contains $21 \%$ oxygen which corresponds to an oxygen partial pressure of $0.021 \mathrm{MPa}$ (norm $\mathrm{pO}_{2}$ ). The loss of vigour and viability during seed ageing is accompanied by accumulated oxidative damage which requires oxygen. Consequently, long-term seed storage at low oxygen concentrations (for example through vacuum packaging) combined with cool and dry conditions are best practice (Schwember and Bradford 2011; Groot et al. 2015). Conversely, dry storage of seeds at 'Elevated Partial Pressure of Oxygen' (EPPO; $18 \mathrm{MPa} \mathrm{pO}_{2}$ ) for 7 weeks, accelerated the seed deterioration processes of lettuce, cabbage and barley, resulting in reduced seed vigour, viability, and the percentage of normal seedlings (Groot et al. 2012). Furthermore, dry storage EPPO treatment of barley and Arabidopsis mapping population seeds delivered quantitative trait loci (QTLs) and proved genetically that EPPO mimics and accelerates dry after-ripening storage and ageing (Nagel et al. 2016; Buijs et al. 2018). EPPO with a 850-fold elevated oxygen partial pressure $\left(\sim 18 \mathrm{MPa} \mathrm{pO}_{2}\right)$ therefore provided a method for analysing seed ageing under dry conditions which is faster (weeks) compared to 'natural' ageing during dry storage (months) in ambient air at norm $\mathrm{pO}_{2}$ (Groot et al. 2012). Short-lived vegetable seeds such as onion or lettuce have typically $4-5 \%$ moisture content in their dry state (at $<15 \% \mathrm{RH}$ ) and such a low seed moisture content is also best for seed long-term dry storage (Nagel and Börner 2010; Schwember and Bradford 2011; Selvi and Saraswathy 2018). Results from classical artificial ageing assays utilising high relative humidity (70-80\% RH) and high temperature (typically $42{ }^{\circ} \mathrm{C}$ ) have been found to elevate the moisture content of the seeds to typically $9-13 \%$. Whether elevated seed moisture combined with high oxygen partial pressure (elevated $\mathrm{pO}_{2}$ ) provide a method for analysing seed ageing and potentially a fast diagnostic assay for seed quality is not known. In the work, we present here we investigated if elevated seed moisture combined with tenfold elevated $\mathrm{pO}_{2}$ compares to classical artificial ageing in assays using very short-lived Allium vegetable seeds.

\section{Materials and methods}

\section{Plant materials}

Salad onion seed of the interspecific Allium cepa $\mathrm{L} . \mathrm{x}$ Allium fistulosum L. cv. Guardsman was harvested from 
plants grown in 2014 at the UK company site (trial seed lot S60/342 (hereafter '342'), Tozer Seeds Ltd. Pyports, Downside Bridge Road, Cobham, Surrey, KT11 3EH, UK) and at the seed production site Klein Karoo in South Africa (trial seed lot '016' and commercial seed). Further to these seed lots, commercial seed of Allium cepa cv. Hyfive (bulb onion) and Allium porrum cv. Lancaster (leek) was used (Table 1). The 1000 kernel weight of A. cepa x A. fistulosum seed was determined according to ISTA (International Seed Testing Association) standard protocols, measured by weighing $8 \times 100$ seeds and extrapolating a mean weight of 1000 seeds. Seed moisture content (SMC, expressed per dry weight) was measured using a moisture analyser ( $n=4 \times 100$, HB43-S, Mettler-Toledo Ltd, Leicester, UK), seed water activity was measured with a water activity meter $(n=3 \times 100$, LabMaster-aw, Novasina AG, Lachen, Switzerland).

\section{Seed ageing treatments}

A classical artificial ageing treatment was applied by subjecting dry seeds ( 4\% SMC) to $70 \%$ relative humidity $(\mathrm{RH}$, in the headspace of a sealed container above $25 \mathrm{~g} / 100 \mathrm{~mL} \mathrm{LiCl}$ ) at $42{ }^{\circ} \mathrm{C}$ for 3,7 and 10 days. These conditions were informed by literature on other Allium seed ageing experiments (Salama and Pearce 1993) and further experimental optimisation of the assay conditions. A control for this classical artificial ageing assay was a 10-day treatment at $70 \% \mathrm{RH}$ at $22{ }^{\circ} \mathrm{C}$. After the treatment, seeds were then dried back to $4 \%$ SMC above silica gel

Table 1 Effect of seed dry storage and ageing treatments on the maximum germination percentages $\left(G_{\max }\right)$ of Allium species seed lots in ambient air

\begin{tabular}{|c|c|c|c|c|c|c|c|}
\hline Allium species & $\begin{array}{l}\text { Cultivar and seed } \\
\text { lot }\end{array}$ & \multirow[t]{2}{*}{$\begin{array}{l}G_{\max }[\%]^{1} \\
\text { before stor- } \\
\text { age }\end{array}$} & \multirow[t]{2}{*}{$\begin{array}{l}\text { Relative humidity } \\
{[\mathrm{RH}] \text { and tempera- }} \\
\text { ture }\left({ }^{\circ} \mathrm{C}\right)\end{array}$} & \multicolumn{3}{|c|}{$\begin{array}{l}\text { Storage or treatment duration } \\
G_{\max }[\%]^{1} \text { after storage or treatment }\end{array}$} & \multirow[t]{2}{*}{ References } \\
\hline \multicolumn{2}{|c|}{ "Natural" ageing during longer dry storage at room temperature (RT) } & & & ca. 8 months & 12 months & 21 months & \\
\hline \multirow{2}{*}{$\begin{array}{l}\text { A. cepa } \times \text { A. fistulo- } \\
\text { sum (Salad onion) }\end{array}$} & Guardsman lot 342 & $91.8 \pm 2.8$ & Desiccant at $22{ }^{\circ} \mathrm{C}$ & - & $72.1 \pm 3.1$ & $60.0 \pm 4.6$ & This work \\
\hline & Guardsman lot 061 & $93.3 \pm 2.0$ & Desiccant at $22^{\circ} \mathrm{C}$ & - & $71.1 \pm 8.0$ & - & This work \\
\hline \multirow[t]{3}{*}{$\begin{array}{l}\text { A. сера } \\
\text { (Bulb onion) }\end{array}$} & Mean of 20 lots & $91.5 \pm 1.2$ & Storage at RT & $49.3 \pm 5.9$ & - & - & $\begin{array}{l}\text { Delouche and Baskin } \\
\text { (1973) }\end{array}$ \\
\hline & Mean of 8 tests $^{2}$ & 80.2 & $66 \% \mathrm{RH}$ at $27^{\circ} \mathrm{C}$ & 37.4 & - & - & Boswell et al. (1940) \\
\hline & Mean of 8 tests $^{2}$ & 80.2 & $44 \% \mathrm{RH}$ at $27^{\circ} \mathrm{C}$ & 72.9 & - & - & Boswell et al. (1940) \\
\hline $\begin{array}{l}\text { A. fistulosum } \\
\text { (Welsh onion) }\end{array}$ & Zhangqiu & $90.6 \pm 7.3$ & $45 \% \mathrm{RH}$ at $\mathrm{RT}$ & - & $57.0 \pm 3.6$ & - & Dong et al. (2014) \\
\hline \multicolumn{4}{|c|}{ Classical artificial ageing at increased humidity and temperature } & $4-5$ days $^{5}$ & $7-8$ days $^{6}$ & 10 or 30 days & \\
\hline A. сера & $\begin{array}{l}\text { Hyfive (commer- } \\
\text { cial seed) }\end{array}$ & $94.5 \pm 3.7$ & $90 \% \mathrm{RH}$ at $42{ }^{\circ} \mathrm{C}$ & - & $28.9 \pm 7.8$ & - & This work \\
\hline A. porrum (Leek) & $\begin{array}{l}\text { Lancaster (com. } \\
\text { seed) }\end{array}$ & $93.3 \pm 1.7$ & $90 \% \mathrm{RH}$ at $42{ }^{\circ} \mathrm{C}$ & $53.3 \pm 7.3$ & $0.0 \pm 0.0$ & - & This work \\
\hline \multirow[t]{3}{*}{$\begin{array}{l}\text { A. cepa } x \text { A. fistu- } \\
\text { losum }\end{array}$} & $\begin{array}{l}\text { Guardsman (com. } \\
\text { seed) }\end{array}$ & $76.7 \pm 1.7$ & $90 \% \mathrm{RH}$ at $42{ }^{\circ} \mathrm{C}$ & $15.0 \pm 2.9$ & $1.7 \pm 1.7$ & - & This work \\
\hline & $\begin{array}{l}\text { Guardsman lot } \\
342^{3}\end{array}$ & $72.1 \pm 3.1$ & $70 \% \mathrm{RH}$ at $42{ }^{\circ} \mathrm{C}$ & - & $60.0 \pm 7.0$ & $50.8 \pm 3.5(10 \mathrm{~d})$ & This work \\
\hline & $\begin{array}{l}\text { Guardsman lot } \\
342^{4}\end{array}$ & $70.0 \pm 6.6$ & $70 \% \mathrm{RH}$ at $22{ }^{\circ} \mathrm{C}$ & - & - & $72.2 \pm 5.0(30 \mathrm{~d})$ & This work \\
\hline \multirow[t]{3}{*}{ A. сера } & Mean of 20 lots & $91.5 \pm 1.2$ & $100 \% \mathrm{RH}$ at $42^{\circ} \mathrm{C}$ & $36.0 \pm 5.5$ & - & - & $\begin{array}{l}\text { Delouche and Baskin } \\
1973\end{array}$ \\
\hline & Mean of 5 lots & $69.6 \pm 6.8$ & $94 \% \mathrm{RH}$ at $42{ }^{\circ} \mathrm{C}$ & $18.8 \pm 4.3$ & - & - & \multirow{2}{*}{$\begin{array}{l}\text { Madruga de Tunes } \\
\text { et al. (2011) }\end{array}$} \\
\hline & Mean of 5 lots & $69.6 \pm 6.8$ & $76 \% \mathrm{RH}$ at $42{ }^{\circ} \mathrm{C}$ & $39.6 \pm 5.9$ & - & - & \\
\hline
\end{tabular}

${ }^{1}$ Mean values \pm SE of at least three replicates each with 30 seeds

${ }^{2}$ Mean of $8 \times 100$-seed tests

${ }^{3}$ Conducted with 12 months stored seeds

${ }^{4}$ Conducted with 24 months stored seeds, $G_{\max }$ values obtained (at $172 \mathrm{~h}$ in the germination kinetics) were not significantly different: $70.0 \pm 6.6 \%$ (without incubation) compared to $72.2 \pm 5.0 \%$ (30 days incubation at $70 \% \mathrm{RH}$ at $22{ }^{\circ} \mathrm{C}$ ). Treatment with $10 \mu \mathrm{M} \mathrm{GA}{ }_{4+7}$ resulted in $81.1 \pm 3.2 \%$ and $78.9 \pm 4.7 \% G_{\max }$, respectively (at $365 \mathrm{~h}$ in the germination kinetics) which verified that most of the non-germinating seeds prior to the GA treatment were not viable

54 days, except for Delouche and Baskin 1973 (5 days)

${ }^{6} 7$ days for $A$. cepa and Guardsman lot 342,8 days for A. porrum and Guardsman commercial seed 
prior to germination assays. As a comparison to a high temperature $\left(42{ }^{\circ} \mathrm{C}\right)$ and moisture $(70 \% \mathrm{RH})$ treatment, we subjected seeds to a high oxygen partial pressure treatment (high $\mathrm{pO}_{2}$ ageing assay). Prior to elevated $\mathrm{pO}_{2}$ treatment, seeds were equilibrated at $70 \% \mathrm{RH}$ (at $22{ }^{\circ} \mathrm{C}$ and norm $\mathrm{pO}_{2}$ ) for 2 days to ensure that they have elevated SMC $(\sim 9.5 \%$ was measured) as in the classical artificial assay. For the high $\mathrm{pO}_{2}$ ageing assay seeds were exposed to compressed air at $0.21 \mathrm{MPa} \mathrm{pO}_{2}$ (10 bar compressed air) for 10 and 30 days at room temperature $\left(22^{\circ} \mathrm{C}\right)$ using a highpressure chamber (3000F01 plant water status console, 0.5 L, Soil Moisture Equipment Corp., Goleta, CA, USA) with a modified chamber cap (Fig. 1a). Compressed air (BOC UN1002 with 250 ppm moisture at 200 bar) will generate $60-70 \% \mathrm{RH}$ at 10 bar. After the high $\mathrm{pO}_{2}$ ageing treatment the seeds were dried back at normal atmospheric pressure to $\sim 4 \%$ SMC above silica gel. As a control for the 30-day high $\mathrm{pO}_{2}$ ageing assay at $22{ }^{\circ} \mathrm{C}$ we conducted a 30-day treatment at $70 \% \mathrm{RH}\left(\right.$ at $22{ }^{\circ} \mathrm{C}$ ).

\section{Scanning electron microscopy (SEM)}

Dry, mature Allium seeds were mounted on $12.5 \mathrm{~mm}$ Cambridge aluminium specimen stubs, sputter-coated with gold (40 nm thickness, Polaron SEM Coating Unit E5100, Bio-Rad Microscience Division, UK) and studied using SEM (Hitachi S-3000 N, Tokyo, Japan) at an acceleration voltage of $20 \mathrm{kV}$.

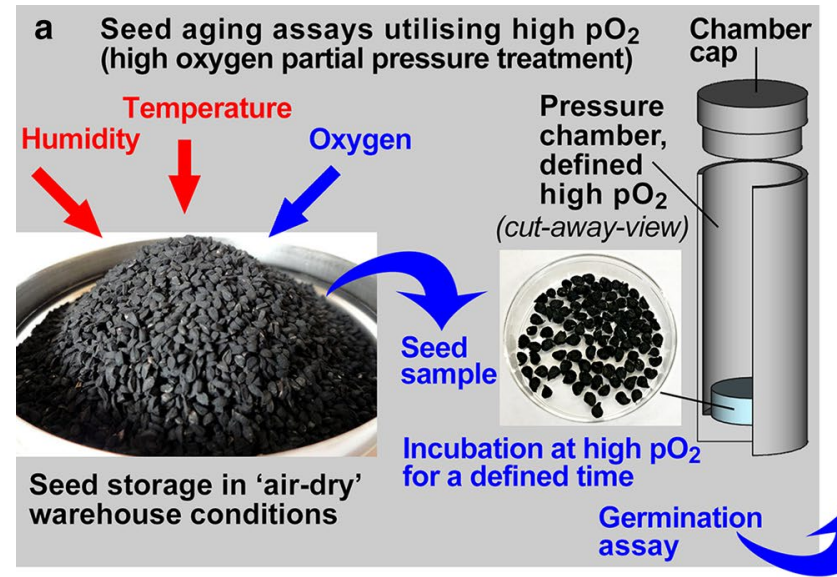

C Allium cepa $\times$ A. fistulosum seed micromorphology
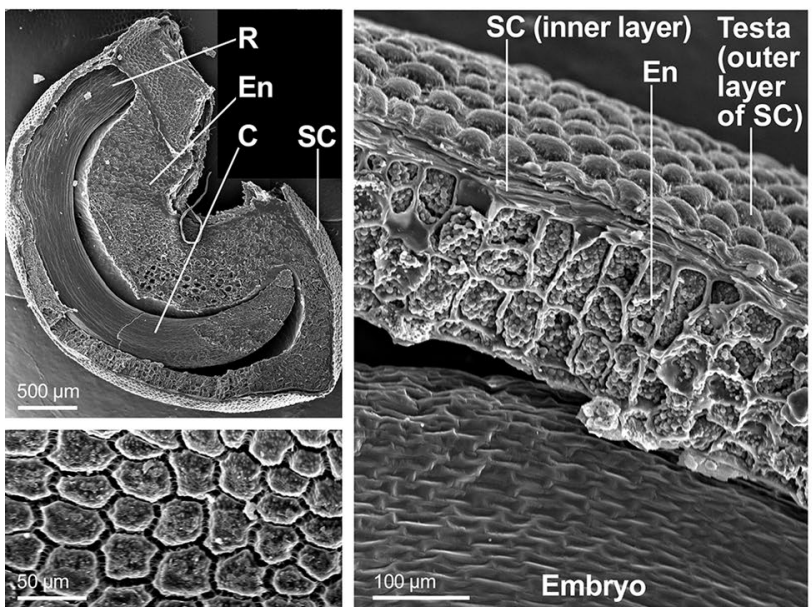

b Allium seed germination and seedling rating

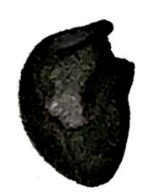

Dry seed

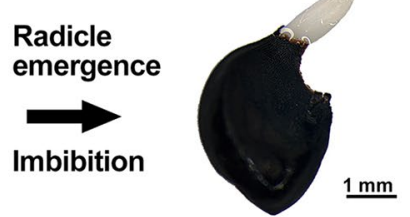

Germinated seed
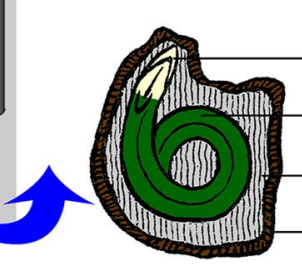

Radicle (R)

R) 1 -Embryo

Cotyledon (C)

Endosperm (En)

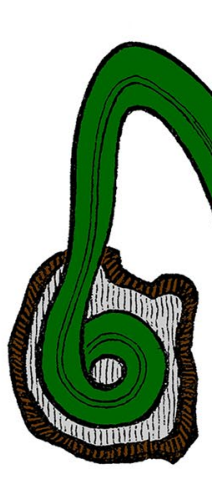

Cotyledon

('bent knee')

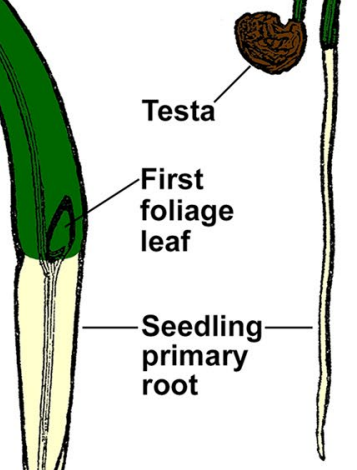

Normal ('usable')

Allium seedling
Fig. 1 Seed micromorphology, germination and ageing assays for Allium species. a Seed ageing of Allium seed utilising a pressure chamber capable of generating and maintaining a defined elevated ambient oxygen partial pressure $\left(\mathrm{pO}_{2}\right)$. Straight arrows depict the three ambient factors that affect aging and seed quality during storage. b Allium seed and seedling structure and germination. Drawings modified from Julius Sachs (1887) Vorlesungen über Pflanzem-Phys- iologie, Verlag von Wilhelm Engelmann, Leipzig. c Seed morphophysiology of the Allium cepa $x$ Allium fistulosum cv. Guardsman analysed by SEM. Left top: Cross section through a mature seed. Left bottom: View onto the outer surface of the testa revealing cell shape and sculpturing; note that this is of taxonomic importance (Celep et al. 2012). Right: Cross section of the seed coat and endosperm layers. $R$ radicle, $E n$ endosperm, $C$ cotyledon, $S C$ seed coat 


\section{Germination and seedling phenotype assays}

Germination assays were conducted under continuous white light $\left(\sim 100 \mu \mathrm{mol} \mathrm{s}^{-1} \mathrm{~m}^{-2}\right)$ at $20^{\circ} \mathrm{C}$ (incubator MLR-352-PE, Panasonic, Osaka, Japan). Onion seeds were incubated in $6 \mathrm{~cm}$ Petri dishes containing two $\varnothing 5 \mathrm{~cm}$ filter paper disks (MN713, Macherey-Nagel, Dueren, Germany) and $2 \mathrm{~mL}$ $\mathrm{dH}_{2} 0+0.3 \%$ PPM $^{\mathrm{TM}}$ (Plant Cell Technology, Washington, DC, USA). Each of 6 replicates consisted of a Petri dish containing 15 onion seeds with germination defined as the radicle protruding through the testa by $1 \mathrm{~mm}$. For seedling phenotype assays onion seeds were incubated at $20{ }^{\circ} \mathrm{C}$ in clear plastic boxes $(118 \mathrm{~mm} \times 176 \mathrm{~mm} \times 42 \mathrm{~mm}$ ) containing a sheet of filter paper and a pleated filter paper (Gilson Scientific Ltd, Houghton Regis, UK) each containing 100 onion seeds and $50 \mathrm{~mL}$ of $\mathrm{dH}_{2} 0$. Seedlings were assessed after 14 days. Normal seedlings were defined as having the primary root intact and the cotyledon with a characteristic bent 'knee'. Abnormal seedlings were typified by a primary root that is stunted and/or displays negative geotropism, cotyledons that are short or undeveloped, a looping or spiral form rather than the presence of a bent 'knee'. Any one of the features of abnormality would result in a seedling being classified as abnormal as such a seedling would not produce a commercially viable ('usable') plant. Testing for abnormality is commonly practiced throughout the seed industry (Ignatz et al. 2019). The maximal germination percentage $\left(G_{\max }\right)$ was calculated from the maximum number of seeds that germinated as a proportion of the total number of seeds and analysed using a generalised linear model with binomial errors using R version 3.6.0 (R Core Team 2019).

\section{Results and discussion}

Seeds of onion (Allium cepa L.) and related Allium species are considered to be among the shortest lived of all common vegetable crops (Boswell et al. 1940; Justice and Bass 1978; Schwember and Bradford 2011; Roberts 2018; Selvi and Saraswathy 2018). These works classify onion, leek, parsnip, pepper and lettuce as examples of short-lived vegetable seeds of storage category 1 typically characterised by only 1-2 years shelf-live (Justice and Bass 1978; Roberts 2018). Table 1 shows that the maximum germination $\left(G_{\max }\right)$ of our salad onion A. cepa $\times$ A. fistulosum cv. Guardsman seed lot 324 decreased from $\sim 92$ to $\sim 60 \%$ during 21 months of dry storage at room temperature. This seed lot had a 1000 seed weight of $5.11 \mathrm{~g}$ and the dry seed had a moisture content of $4.2 \pm 0.1 \%$ corresponding to a water activity of $a_{\mathrm{w}}=0.33 \pm 0.01$. That the observed reduction in maximum germination $\left(G_{\max }\right)$ is in fact due to a reduction in lot viability by progressing death of individual seeds and not by the induction of secondary physiological dormancy
(Finch-Savage and Leubner-Metzger 2006) was verified by gibberellin treatment which demonstrated that most of the non-germinating seeds were indeed dead (Table 1). A rapid reduction in seed lot viability caused by 'natural' ageing during long-term storage in the dry state (4-6\% SMC) is likewise evident for other Allium species (Table 1). With at least 660 species, the monocotyledon genus Allium is one of the largest, harbouring major vegetable crops including A. cepa (common or bulb onion), A. fistulosum (Welsh or Japanese bunching onion), A. sativum (garlic), A. porrum (leek), and A. schoenoprasum (Brewster 2008; Dong et al. 2014; Hauenschild et al. 2017; Selvi and Saraswathy 2018). A number of hybrids are cultivated as salad or spring onions that have the closely related A. cepa and A. fistulosum species as parents (Hauenschild et al. 2017; Kudryavtseva et al. 2019). In addition to their economic importance, the very short shelf-life of Allium vegetable seeds provide an excellent system to study the mechanisms of seed ageing and to develop diagnostic assays.

In a mature Allium seed, the fully developed embryo is embedded in a living endosperm tissue which is surrounded by a dead seed coat (Fig. 1). Radicle emergence was used as visible event to mark the completion of seed germination. Subsequent embryo growth into a normal seedling ('usable' for primary crop production) is characterised by the development of an intact primary root and a cotyledon with a characteristic bent 'knee' (Fig. 1b). As for all Allium seeds, the A. cepa $\times$ A. fistulosum outer seed coat layer (testa) is black (Fig. 1b) and the micromorphology of the testa cells (Fig. 1c) is very similar if not identical to A. cepa and $A$. fistulosum for which irregular polygonal, loose cell shapes are characteristic (Celep et al. 2012; Choi et al. 2012; Lin and Tan 2017). Between the A. cepa $x$ A. fistulosum testa and endosperm layers is a layer of crushed seed coat cells (Fig. 1c) the location and structure of which corresponds to the semipermeable seed coat layer characterised microscopically and biochemically in onion seeds (Beresniewicz et al. 1995a, b, c). Maintaining seed quality during dry seed storage is dependent on the properties of the seed coat which mediates moisture uptake and gas exchange. Mechanical damage is known to reduce the quality of dry onion seeds (Pedretti et al. 2017), but as our micromorphological analysis of dry A. cepa $x$ A. fistulosum seeds did not reveal any obvious damage (Fig. 1) we used seed lots of this and other Allium species to optimise the conditions for the classical artificial aging assays (Table 1).

In both 'naturally' aged (dry stored long-term dry storage $~ 5 \%$ SMC, Table 1) and in classical artificial ageing assays at $70-90 \% \mathrm{RH}$ and $42{ }^{\circ} \mathrm{C}$ a rapid decline in seed lot viability was observed for different Allium species (Table 1). After 2 days of equilibration at $70 \% \mathrm{RH}$ our Allium 342 seed lot had a $9.5 \pm 0.3 \%$ SMC; $70-80 \%$ $\mathrm{RH}$ is known to elevate the Allium SMC to $\sim 9-13 \%$ and 
90-100\% RH to $>15 \%$ (Boswell et al. 1940; Salama and Pearce 1993; Madruga de Tunes et al. 2011; Schwember and Bradford 2011; Selvi and Saraswathy 2018). A temperature of $40-50{ }^{\circ} \mathrm{C}$ combined with $70-100 \% \mathrm{RH}$ was found to provide optimal assays for Allium seed lots (Boswell et al. 1940; Delouche and Baskin 1973; Justice and Bass 1978; Salama and Pearce 1993; Madruga de Tunes et al. 2011; Schwember and Bradford 2011; Selvi and Saraswathy 2018). A temperature of $42{ }^{\circ} \mathrm{C}$ was used in most of these classical artificial ageing assay including in our works (Table 1). Submitting our A. cepa $x$ A. fistulosum seed lot 342 to $42{ }^{\circ} \mathrm{C}$ combined with $70 \%$ RH for 10 days reduced $G_{\max }$ from 72.1 to $50.8 \%$. In contrast to $42{ }^{\circ} \mathrm{C}$, the $G_{\max }$ of the control treatment at $22{ }^{\circ} \mathrm{C}(70 \% \mathrm{RH}$, 10 days) was $76.0 \%$, clearly demonstrating that elevated SMC alone is not reducing the seed lot viability (Table 1). Figure 2a shows that our classical artificial ageing assay caused a progressive and rapid viability loss, the severity of which increased with the duration of the treatment. This loss in seed lot viability was not preceded by a visible decline in speed ( $T_{50 \%}$ of $G_{\max }$ ) or vigour as is known from lettuce and many other species (Schwember and Bradford 2011; Groot et al. 2012; Finch-Savage and Bassel 2016). It rather seems that for individual Allium seeds, ageing may trigger a switch towards seed death and hence without

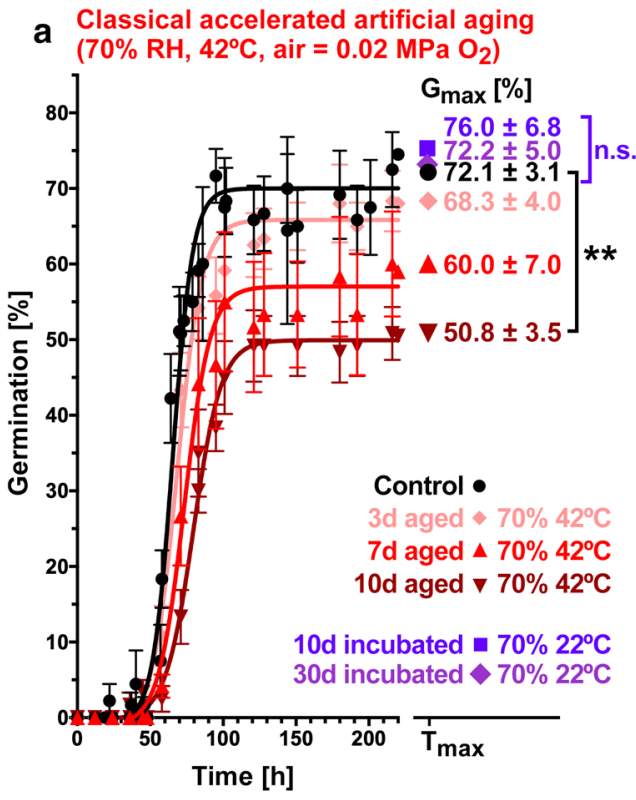

Fig. 2 The comparison of seed ageing assays. a Classical artificial $\left(70 \% \mathrm{RH}, 42{ }^{\circ} \mathrm{C}\right.$ ) and $\mathbf{b}$ high oxygen partial pressure (elevated $\mathrm{pO}_{2}$ ) seed ageing assays of the Allium cepa x Allium fistulosum cv. Guardsman. $G_{\max }$ values shown are means \pm standard error. Control treatments include incubation for 10 and 30 days at $70 \% \mathrm{RH}$ and $22{ }^{\circ} \mathrm{C}$ which does not affect the $G_{\max }$, which demonstrated that the elevated SMC alone does not cause seed viability loss. A $10 \mu \mathrm{M}$ gibberellin $\mathrm{A}_{4+7}(\mathrm{GA})$ treatment does not affect the $G_{\max }$ and thereby demon- an apparent decline in seed lot germination speed causes a rapid decline in seed lot viability (Fig. 2 and Table 1).

To assess how ageing of short-lived Allium seeds compares in high $\mathrm{pO}_{2}$ versus classical artificial seed ageing assays, we first equilibrated the salad onion (A. cepa $\times \mathrm{A}$. fistulosum cv Guardsman) seeds at $22{ }^{\circ} \mathrm{C}$ in $70 \% \mathrm{RH}$ to ensure that the same elevated SMC $(9.5 \pm 0.3 \%)$ is reached. The seeds were subsequently incubated either in the classical artificial ageing assay $\left(70 \% \mathrm{RH}, 42{ }^{\circ} \mathrm{C}\right)$ for 3-10 days (Fig. 2a) or in a pressure chamber (Fig. 1a) for the high $\mathrm{pO}_{2}$ assay at tenfold elevated $\mathrm{pO}_{2}\left(0.21 \mathrm{MPa} \mathrm{O}_{2}, 70 \% \mathrm{RH}, 22^{\circ} \mathrm{C}\right)$ for several days (Fig. 2b). Subsequent analysis of germination data demonstrated that 30 days high $\mathrm{pO}_{2}$ treatment significantly reduced $(P<0.05)$ the maximum germination percentage $\left(G_{\max }\right)$ from 72 to $\sim 58 \%$ while 10 days high $\mathrm{pO}_{2}$ treatment did not affect the germination response (Fig. 2a). The $\sim 14 \%$ reduction in $G_{\max }$ by 30 days high $\mathrm{pO}_{2}$ seed ageing was due to loss of seed viability. As for the classical artificial ageing, gibberellin treatment was used to verify that the observed reduction in seed lot $G_{\max }$ was indeed due to a reduction in seed lot viability (Fig. 2). As in the classical artificial ageing assay (humidity $\times$ high temperature $42{ }^{\circ} \mathrm{C}$ ) the major response of the Allium seed population was, therefore, a reduction in $G_{\max }$ due to loss of seed viability. Compared to the seed ageing responses in the classical artificial

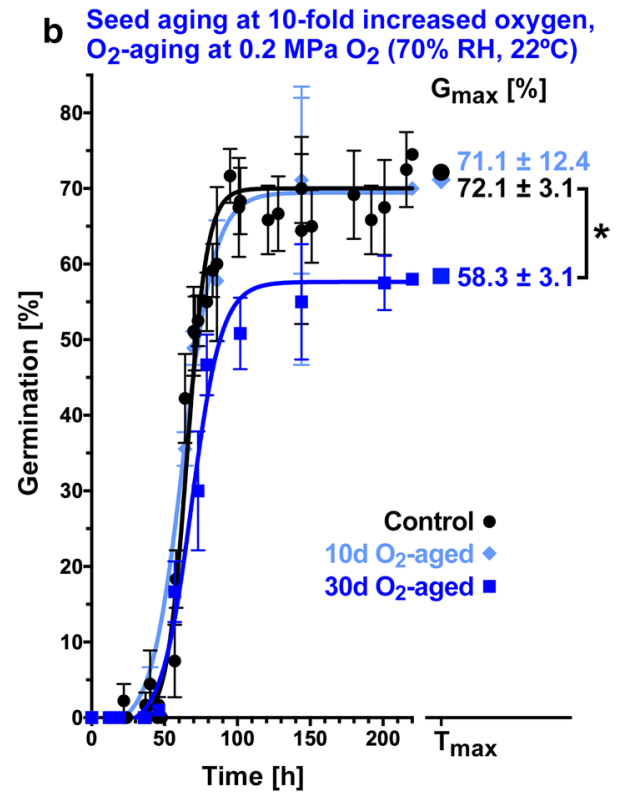

strated that non-germinating seeds are dead: GA-treatment of 30-day elevated $\mathrm{pO}_{2}$ aged seeds resulted in a $G_{\max }$ of $50.8 \pm 16.3 \%$ which is statistically not different to the not GA-treated seeds. The same conclusion was obtained from GA-treatment of control seeds (see Table 1 for $\left.G_{\max }\right)$. Statistically significant differences between $G_{\max }$ values are denoted as $* p<0.05$ and $* * p<0.01$; n.s., not significant. $T_{\max }$ is the maximum time of the germination assay and is between 225 and $280 \mathrm{~h}$ 
ageing assay (Fig. 1a) the 30 days high $\mathrm{pO}_{2}$ seed ageing corresponds to approximately 7 days ageing at humidity $\mathrm{x}$ high temperature (Fig. 2). No appreciable reduction in germination speed or vigour was evident in the Allium seed samples, the major effect in both ageing assays was due to the rapid loss in seed viability of a proportion of seeds in the population. We, therefore, show here that tenfold elevated $\mathrm{pO}_{2}$ $\left(0.21 \mathrm{MPa} \mathrm{O}_{2}\right)$ caused a rapid loss in seed viability per se at room temperature after 30 days (Fig. 2b). A rapid loss of seed viability in both seed ageing assays for Allium suggest that oxidation processes including lipid oxidation is a major mechanism for the oxygen-dependent seed ageing of Allium (Salama and Pearce 1993; Bailly 2004; Nagel and Börner 2010; Groot et al. 2012; Sano et al. 2016). A recent study on 'natural' ageing by 5-40 years seed dry storage of wheat and barley demonstrated that also the long-term age-dependent loss of seed viability is associated with increased lipid oxidation (Wiebach et al. 2019). The salad onion (A. cepa $x$ A. fistulosum cv. Guardsman) cultivar used in our study represents a very typical commercial Allium seed lot based on Tozer's experience as a seed company. That this is indeed the case was confirmed in our work by the expanded analysis of 'natural' and classical artificial ageing across other Allium species and seed lots (Table 1). From these results, the observed rapid seed viability loss indeed seems to be a hallmark of Allium seed ageing during storage. We observed the rapid loss in seed viability response also after 30 days in the tenfold elevated $\mathrm{pO}_{2}$ ageing assay with the specific seed lot used in our experiment (Fig. 2b). Because we obtained a typical Allium seed ageing response, namely viability loss, we suppose that this is a more general response for Allium seed ageing during storage in any quality assay. Further work with several Allium seed lots to analysing the duration and intensities of humidity, temperature, and oxygen as seed ageing assay factors is therefore required and should also be expanded to other species with short seed shelf-life.

A rapid loss of Allium maximal seedling emergence in

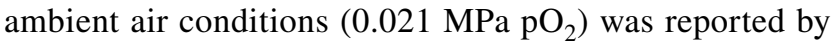
using classical accelerated ageing assays (Salama and Pearce 1993) and controlled deterioration assays on the percentage of normal seedlings (Schwember and Bradford 2011). These results allow no distinction between seed viability per se and the negative effects of the ageing on seedlings (death/ abnormality) from the germinating seeds of the population. Groot et al. (2012) showed that dry storage EPPO treatment of lettuce seeds with 850-fold elevated $\mathrm{pO}_{2}\left(18 \mathrm{MPa} \mathrm{O}_{2}\right)$ reduced germination speed and maximum germination of the lots. For seed lots stored for at least 3 years in warehouse conditions, it also increased the number of abnormal lettuce seedlings. Normal, usable seedlings are key for the crop seed industry and the dry storage EPPO treatment, therefore, provided a fast method for analysing lettuce seed lot quality during long-term dry storage (Groot et al. 2012). In contrast to this, our results with Allium seedlings (Fig. 3) showed that neither the classical nor the high $\mathrm{pO}_{2}$ treatment with tenfold elevated $\mathrm{pO}_{2}\left(0.21 \mathrm{MPa} \mathrm{O}_{2}\right)$ affected the incidence of abnormal seedlings originating from the viable seeds which are germinating. Because it is faster, the optimised classical artificial ageing assay based on elevated RH and temperature is more suited for testing Allium seed quality. It seems that Allium species are very sensitive to seed ageing and instantly respond with a rapid loss of seed viability while species with a longer 'shelf-life' respond with vigour loss and subsequently with a slow loss of seed viability. The mechanisms and genetics (Nagel et al. 2016; Sano et al. 2016; Buijs et al. 2018; Schausberger et al. 2019) underpinning the distinct sensitivities to dry storage EPPO treatment and high $\mathrm{pO}_{2}$ treatment of seeds equilibrated to a higher $\mathrm{SMC}$ is a timely topic for future research. It has been proposed from experiments with onion and lettuce comparing seed ageing at low and normal $\mathrm{pO}_{2}$ that different molecular mechanisms may be involved in seed ageing at different moisture levels and that norm $\mathrm{pO}_{2}$ levels are more harmful to seeds at lower SMC compared to elevated SMC (Ibrahim et al. 1983; Ellis and Hong 2007; Schwember and Bradford 2011). The level of peroxidation was proposed to be an important difference between fast and slow ageing seeds, but the speed of deterioration also depends on the cellular redox
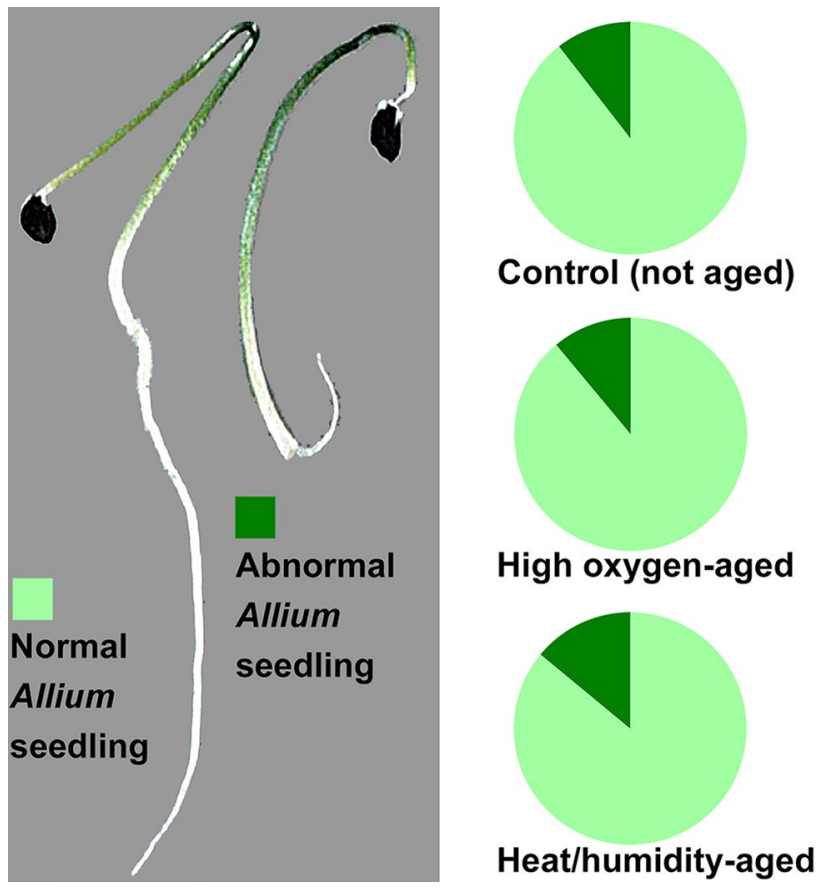

Fig. 3 Summary of Allium cepa $x$ Allium fistulosum cv. Guardsman seedlings developing from the germinated (viable) seeds of the seed populations, subjected to either 30 days high $\mathrm{pO}_{2}$ or 7 days classical artificial seed ageing assay conditions. Left: Effect of ageing on Allium seedling phenology. Right: Pie charts presenting the relative proportions of normal and abnormal Allium seedlings 
environment, changes in $\mathrm{pH}$, storage compounds and genotype (Salama and Pearce 1993; Selvi and Saraswathy 2018; Nagel et al. 2019). Our findings with Allium seed ageing at elevated SMC demonstrate that the combination with either elevated $\mathrm{pO}_{2}$ or temperature both cause rapid seed viability loss without appreciably affecting germination speed. Shortlived Allium vegetable seeds, therefore, provide an excellent system to study the biochemical mechanisms of seed lot viability loss per se using ageing assays in which the distinct contributions of all three ambient cues (humidity, temperature, oxygen) can be investigated individually and in combination.

Author contributions Statement MP, TS, FG, JEH and GL-M planned and designed the research; JEH, TS and MR performed experiments; MP, FG and MR provided material or equipment; TS, JEH, and GL-M analysed and interpreted the data; JEH and GL-M wrote the manuscript with contributions of all authors.

Acknowledgements We thank Sharon Gibbons for assistance with the electron microscopy, Sue Stagg for expert technical support with germination assays and Giles Grainge for the A. cepa Hyfive data in Table 1. This work was supported by the Industrial Strategy Challenge Fund (ISCF) Wave1 AgriTech by Innovate UK and the Biotechnology and Biological Sciences Research Council (BBSRC) to GL-M, TS and MP (BB/R021147/1) and to Tozer Seeds (TSB132858).

\section{Compliance with ethical standards}

Conflict of interest The authors declare that they have no competing interests.

Data Availability Statement All data presented or analysed in this published article are available online through figshare https://doi. org/10.17637/rh.9742316.

Open Access This article is licensed under a Creative Commons Attribution 4.0 International License, which permits use, sharing, adaptation, distribution and reproduction in any medium or format, as long as you give appropriate credit to the original author(s) and the source, provide a link to the Creative Commons licence, and indicate if changes were made. The images or other third party material in this article are included in the article's Creative Commons licence, unless indicated otherwise in a credit line to the material. If material is not included in the article's Creative Commons licence and your intended use is not permitted by statutory regulation or exceeds the permitted use, you will need to obtain permission directly from the copyright holder. To view a copy of this licence, visit http://creativecommons.org/licenses/by/4.0/.

\section{References}

Bailly C (2004) Active oxygen species and antioxidants in seed biology. Seed Sci Res 14:93-107

Beresniewicz MM, Taylor AG, Goffinet MC, Koeller WD (1995a) Chemical nature of a semipermeable layer in seed coats of leek, onion (Liliaceae), tomato and pepper (Solanaceae). Seed Sci Technol 23:135-145

Beresniewicz MM, Taylor AG, Goffinet MC, Terhune BT (1995b) Characterization and location of a semipermeable layer in seed coats of leek and onion (Liliaceae), tomato and pepper (Solanaceae). Seed Sci Technol 23:123-134

Beresniewicz MM, Taylor AG, Goffinet MC, Terhune BT (1995c) Seed coat integrity in relation to leakage in onion (Allium cepa L.) and leek (Allium porrum L.). Plant Var Seeds 8:87-95

Borisjuk L, Rolletschek H (2009) The oxygen status of the developing seed. New Phytol 182:17-30

Boswell VR, Fisher DF, Toole EH, Toole VK (1940) A study of rapid deterioration of vegetable seeds and methods for its prevention. USA Dept Agric Tech Bull 708:1-4 (Washington, DC, USA)

Brewster J (2008) Onions and other vegetable Alliums. CABI Horticulture Research International, Wellesbourne

Buijs G, Kodde J, Groot SPC, Bentsink L (2018) Seed dormancy release accelerated by elevated partial pressure of oxygen is associated with DOG loci. J Exp Bot 69:3601-3608

Celep F, Koyuncu M, Fritsch RM, Kahraman A, Dogan M (2012) Taxonomic importance of seed morphology in Allium (Amaryllidaceae). Syst Bot 37:893-912

Chen H, Osuna D, Colville L, Lorenzo O, Graeber K, Kuster H, Leubner-Metzger G, Kranner I (2013) Transcriptome-wide mapping of pea seed ageing reveals a pivotal role for genes related to oxidative stress and programmed cell death. PLoS One 8:e78471

Choi HJ, Giussani LM, Jang CG, Oh BU, Cota-Sanchez JH (2012) Systematics of distunct northeastern Asian and norhern North American Allium (Amaryllidaceae). Botany 90:491-508

Colville L, Pritchard HW (2019) Seed life span and food security. New Phytol 224:557-562

Darwin CR (1855) Longevity of seeds. Gard Chron Agric Gazette $52: 854$

Delouche JC, Baskin CC (1973) Accelerated aging techniques for predicting the relative storability of seed lots. Seed Sci Technol $1: 427-452$

Dong L, Hao Z, Li Z, Zhu J, Wang Q (2014) Enhancement of Welsh onion (Allium fistulosum L.) seed vigor by $\mathrm{KNO}_{3}$ priming. J Agr Sci Tech Iran 16:1345-1353

Ellis RH, Hong TD (2006) Temperature sensitivity of the low-moisture-content limit to negative seed longevity-moisture content relationships in hermetic storage. Ann Bot 97:785-791

Ellis RH, Hong TD (2007) Seed longevity - moisture content relationships in hermetic and open storage. Seed Sci Technol 35:423-431

Ellis RH, Hong TD, Roberts EH, Tao K-L (1990) Low moisture content limits to relations between seed longevity and moisture. Ann Bot 65:493-504

Finch-Savage WE, Bassel GW (2016) Seed vigour and crop establishment: extending performance beyond adaptation. J Exp Bot 67:567-591

Finch-Savage WE, Leubner-Metzger G (2006) Seed dormancy and the control of germination. New Phytol 171:501-523

Gardarin A, Durr C, Mannino MR, Busset H, Colbach N (2010) Seed mortality in the soil is related to seed coat thickness. Seed Sci Res 20:243-256

Groot SPC, Surki AA, de Vos RC, Kodde J (2012) Seed storage at elevated partial pressure of oxygen, a fast method for analysing seed ageing under dry conditions. Ann Bot 110:1149-1159

Groot SPC, de Groot L, Kodde J, van Treuren R (2015) Prolonging the longevity of ex situ conserved seeds by storage under anoxia. Plant Genet Resour C 13:18-26

Hauenschild F, Favre A, Schnitzler J, Michalak I, Freiberg M, Muellner-Riehl AN (2017) Spatio-temporal evolution of Allium L. in the Qinghai-Tibet-Plateau region: immigration and in situ radiation. Plant Diver 39:167-179 
Hermann K, Meinhard J, Dobrev P, Linkies A, Pesek B, Heß B, Machackova I, Fischer U, Leubner-Metzger G (2007) 1-Aminocyclopropane-1-carboxylic acid and abscisic acid during the germination of sugar beet (Beta vulgaris L.) - a comparative study of fruits and seeds. J Exp Bot 58:3047-3060

Ibrahim AE, Roberts EH, Murdoch AJ (1983) Viability of lettuce seeds 2. Survival and oxygen-uptake in osmotically controlled storage. J Exp Bot 34:631-640

Ignatz M, Hourston JE, Tureckova V, Strnad M, Meinhard J, Fischer U, Steinbrecher T, Leubner-Metzger G (2019) The biochemistry underpinning industrial seed technology and mechanical processing of sugar beet. Planta 250:1717-1729

Justice OL, Bass LN (1978) Principles and practices of seed storage. United States Department of Agriculture, Agriculture Handbook 506, Washington DC, USA

Kranner I, Minibayeva FV, Beckett RP, Seal CE (2010) What is stress? Concepts, definitions and applications in seed science. New Phytol 188:655-673

Kudryavtseva N, Havey MJ, Black L, Hanson P, Sokolov P, Odintsov S, Divashuk M, Khrustaleva L (2019) Cytological evaluations of advanced generations of interspecific hybrids between Allium cepa and Allium fistulosum showing resistance to Stemphylium vesicarium. Genes 10:195

Lin CY, Tan DY (2017) Seed testa micromorphology of thirty-eight species of Allium (Amaryllidaceae) from central Asia, and its taxonomic implications. Nordic J Bot 35:189-200

Madruga de Tunes L, Tavares LC, de Araujo RC, Vieira JF, dos Santos AT, Barros GCSA, Muniz MFB (2011) Accelerated aging of onion seeds (Allium cepa $\mathrm{L}$.) submitted to saturated salt solutions. Revista Colombiana de Ciencias Horticolas 5:244-250

Mene-Saffrane L, Jones AD, DellaPenna D (2010) Plastochromanol-8 and tocopherols are essential lipid-soluble antioxidants during seed desiccation and quiescence in Arabidopsis. Proc Natl Acad Sci USA 107:17815-17820

Mohamed-Yasseen Y, Barringer SA, Splittstoesser WE, Constanza S (1994) The role of seed coats in seed viability. Bot Rev 60:426-439

Nagel M, Börner A (2010) The longevity of crop seeds stored under ambient conditions. Seed Sci Res 20:1-12

Nagel M, Kranner I, Neumann K, Rolletschek H, Seal CE, Colville L, Fernandez-Marin B, Börner A (2015) Genome-wide association mapping and biochemical markers reveal that seed ageing and longevity are intricately affected by genetic background and developmental and environmental conditions in barley. Plant Cell Environ 38:1011-1022

Nagel M, Kodde J, Pistrick S, Mascher M, Börner A, Groot SPC (2016) Barley seed aging: genetics behind the dry elevated pressure of oxygen aging and moist controlled deterioration. Front Plant Sci $7: 388$

Nagel M, Seal CE, Colville L, Rodenstein A, Un S, Richter J, Pritchard HW, Börner A, Kranner I (2019) Wheat seed ageing viewed through the cellular redox environment and changes in $\mathrm{pH}$. Free Radical Res 53:641-654

Pedretti EF, Duca D, Toscano G, Mengarelli C, Rossini G, Pizzi A, Mancini M, Tesei D, Ilari A (2017) Validity of the mechanical threshing of onion seeds from the point of view of seed quality. Agriculture 7:102
Powell AA, Matthews S (1981) Evaluation of controlled deterioration, a new vigor test for small seeded vegetables. Seed Sci Technol 9:633-640

Pritchard HW, Dickie JB (2004) Predicting seed longevity. In: Pritchard HW, Probert RJ, Smith RD, Dickie JB, Linington SH (eds) Seed conservation: turning science into practice. Royal Botanic Gardens, Kew, London, pp 654-721

Probert RJ, Daws MI, Hay FR (2009) Ecological correlates of ex situ seed longevity: a comparative study on 195 species. Ann Bot 104:57-69

R Core Team (2019) R: A language and environment for statistical computing. R Foundation for Statistical Computing, Vienna

Roberts S (2018) Vegetable seed quality, storage and handling: AHDB Factsheet. Agriculture and Horticulture Development Board, Kenilworth, vol 3

Salama AM, Pearce RS (1993) Aging of cucumber and onion seedsphospholipase $\mathrm{D}$, lipoxygenase activity and changes in phospholipid content. J Exp Bot 44:1253-1265

Salimi Z, Boelt B (2019) Classification of processing damage in sugar beet (Beta vulgaris) seeds by multispectral image analysis. Sensors 19:2360

Sano N, Rajjou L, North HM, Debeaujon I, Marion-Poll A, Seo M (2016) Staying alive: molecular aspects of seed longevity. Plant Cell Physiol 57:660-674

Schausberger C, Roach T, Stoggl W, Arc E, Finch-Savage WE, Kranner I (2019) Abscisic acid-determined seed vigour differences do not influence redox regulation during ageing. Biochem J 476:965-974

Schwember AR, Bradford KJ (2011) Oxygen interacts with priming, moisture content and temperature to affect the longevity of lettuce and onion seeds. Seed Sci Res 21:175-185

Selvi DT, Saraswathy S (2018) Seed viability, seed deterioration and seed quality improvements in stored onion seeds: a review. J Hortic Sci Biotechnol 93:1-7

Steinbrecher T, Leubner-Metzger G (2017) The biomechanics of seed germination. J Exp Bot 68:765-783

Walck JL, Hidayati SN, Dixon KW, Thompson K, Poschlod P (2011) Climate change and plant regeneration from seed. Global Change Biol 17:2145-2161

Walters C (2015) Orthodoxy, recalcitrance and in-between: describing variation in seed storage characteristics using threshold responses to water loss. Planta 242:397-406

Walters C, Wheeler LM, Grotenhuis JM (2005) Longevity of seeds stored in a genebank: species characteristics. Seed Sci Res $15: 1-20$

Waterworth WM, Masnavi G, Bhardwaj RM, Jiang Q, Bray CM, West CE (2010) A plant DNA ligase is an important determinant of seed longevity. Plant J 63:848-860

Wiebach J, Nagel M, Börner A, Altmann T, Riewe D (2019) Agedependent loss of seed viability is associated with increased lipid oxidation and hydrolisis. Plant Cell Environ 43:303-314

Publisher's Note Springer Nature remains neutral with regard to jurisdictional claims in published maps and institutional affiliations. 